Bond University

Research Repository

\title{
A Review of Money Laundering Literature: The State of Research in Key Areas
}

Tiwari, Milind; Gepp, Adrian; Kumar, Kuldeep

Published in:

Pacific Accounting Review

DOI:

10.1108/PAR-06-2019-0065

Licence:

Other

Link to output in Bond University research repository.

Recommended citation(APA):

Tiwari, M., Gepp, A., \& Kumar, K. (2020). A Review of Money Laundering Literature: The State of Research in Key Areas. Pacific Accounting Review, 32(2), 271-303. https://doi.org/10.1108/PAR-06-2019-0065

\footnotetext{
General rights

Copyright and moral rights for the publications made accessible in the public portal are retained by the authors and/or other copyright owners and it is a condition of accessing publications that users recognise and abide by the legal requirements associated with these rights.
}

For more information, or if you believe that this document breaches copyright, please contact the Bond University research repository coordinator. 


\title{
A Review of Money Laundering Literature: The State of Research in Key Areas
}

Single Sentence Summary: A review of relevant literature highlights the need to focus on shell companies when detecting money laundering activities.

\begin{abstract}
:
Purpose: The purpose of this study is to review the literature on money laundering and its related areas. The main objective is to identify any gaps in the literature and direct attention towards addressing them.
\end{abstract}

Design/Methodology/Approach: A systematic review of the money laundering literature was conducted with an emphasis on the Pro-Quest, Scopus and Science-Direct databases. Broad research themes were identified after investigating the literature. The theme about the detection of money laundering was then further investigated. The major approaches of such detection are identified as well as research gaps that could be addressed in future studies.

Findings: The literature on money laundering can be classified into the following six broad areas: (i) anti-money laundering framework and its effectiveness, (ii) the effect of money laundering on other fields and the economy, (iii) the role of actors and their relative importance, (iv) the magnitude of money laundering, (v) new opportunities available for money laundering and (vi) detection of money laundering. Most studies about the detection of money laundering have focused on the use of innovative technologies, banking transactions, or real estate and trade-based money laundering. However, the literature on the detection of shell companies being explicitly used to launder funds is relatively scarce.

Originality/Value: This paper provides insights into an area related to money laundering where research is relatively scant. Shell companies incorporated in the UK alone were identified to be associated with laundering 80 billion pounds of stolen money between 2010 and 2014. The use of these entities to launder billions of dollars as witnessed through the laundromat schemes and several data leaks clearly indicate the need to focus on illicit financial flows through such entities.

Keywords: Money Laundering, Shell Companies, Illicit Activities, Detection, Accounting, Professionals

Type: Literature Review 


\section{Introduction}

The problem of money laundering was highlighted in 1998 by the then-director of the International Monetary Fund (IMF), who estimated the amount of money being laundered to be between two and five per cent of global Gross Domestic Product (GDP) (Camdessus, 1998). In a recent example, the Organized Crime and Corruption Reporting Project (OCCRP) uncovered the "Troika Laundromat" that involved moving billions of dollars of illicit Russian funds through the use of secretive offshore companies (OCCRP, 2019). In another example, shell companies incorporated in the UK alone were identified to be associated with laundering 80 billion pounds of stolen money between 2010 and 2014 (Cowdock, 2017).

Money laundering is the act of giving dirty money a legitimate appearance. According to the United Nations (UN) 2000 Convention (UNODC, 2004), money laundering is the process of converting or transferring the asset with knowledge of its being derived from a criminal source, with an aim to conceal that criminal source or aid the criminal involved in committing the crime. Efforts are made towards disguising the nature and origin of the illicit income generated and integrating it into the financial system without drawing attention from tax authorities or law enforcement agencies (Compin, 2008). Apart from a range of underground activities such as drug trafficking, cybercrime, corruption and so forth, there are quasi-legal activities involving the concealment of income from public authorities. Such acts produce the shadow economy (Schneider and Windischbauer, 2008, Schneider, 2010). They also contribute to money laundering. According to Buchanan (2004), the process of money laundering comprises three stages, namely placement, layering and integration.

With the growing concerns in the US regarding the movements of funds across borders for tax evasion or the use of cash-intensive businesses such as casinos to conceal the origin of funds, the need to monitor money laundering activities has gained prominence (Levi and Reuter, 2009, Van Duyne, 2003). However, money laundering was criminalised as far back as 1986. The Money Laundering Control Act, 1986, passed in the US, was introduced to tackle the illicit proceeds from acts of bribery, extortion and fraud with a special emphasis on illegal drug trafficking. The idea was to aid in the war against drugs by reducing profitability of organised crime from criminal activities. Additionally, a prevailing global belief was that in an effort to hide and conceal the illicit funds, they were being moved to offshore jurisdictions and tax havens. Subsequently, the phenomenon of money laundering garnered attention as a threat to legitimacy and stability of financial systems and a source of reputational risk (Van Duyne and Levi, 2005). All these factors paved the way for the 
emergence of a consensus among global economic powers to develop and initiate a coordinated response to tackle the problem of money laundering.

The first global response was the UN's 1988 Convention against narcotics and other such substances, popularly known as the Vienna Drug Convention. The convention made offenders subject to prosecution if found trying to launder illicit wealth earned from production and sales of narcotics. The Financial Action Task Force (FATF) was formed in 1989 by The Group of Seven (G7) to combat the growing problem. The FATF expanded the scope of the definition of money laundering by criminalising proceeds derived from other illicit sources such as illegal arms sales, insider trading, embezzlement, bribery and fraud among others. Since then, in an attempt to curb this growing problem, the scope of money laundering regulation has been regularly widened further, such as to include activities financing the act of terrorism (Unger, 2013).

The recently identified data leaks such as the Paradise Papers, the Panama Papers and the Offshore leaks have directed attention towards the scale and effect of money laundering activities at a global level. As a result, it becomes imperative to understand the work done around these at a global level. Additionally, the use of shell companies to undertake these activities to launder the illicit proceeds, as observed in laundromat schemes such as the Troika Laundromat ${ }^{1}$ and the Azerbaijani Laundromat ${ }^{2}$ (OCCRP, 2017, OCCRP, 2019), gives rise to the need for reviewing the literature on shell companies. To the best of our knowledge, there does not yet exist a review to unite such a multi-faceted literature. We aim to address this issue and subsequently motivate substantial progress on this important research area.

\section{The literature review process}

A systematic approach was used to investigate the current literature on money laundering and shell companies. First, Pro-Quest, Scopus and Science-Direct were searched for papers that contained the keywords "money launder*" in the title, abstract or keywords. Additional articles were obtained by investigating cited references and conducting Google Scholar searches. After an initial review of these papers, additional searches were conducted using keywords found in those articles. The additional search keywords were "shell compan*","shell firm*", "anonymous compan*", "front compan*”, "phantom firm*", "dormant compan*", and "sham corporation*" as documented in Table 1 .

\footnotetext{
${ }^{1}$ The Troika Laundromat collectively refers to a group of shell companies operated by an independent arm of Troika Dialog, a Russian investment bank, to move an estimated USD 8.8 billion from Russia to the west. 2 The Azerbaijani Laundromat refers to a complex money laundering operation and slush fund that laundered over USD 2.9 billion through four shell companies registered in the UK over the course of two years.
} 


\section{--Insert approximately here-- Table I. Search Log with keywords}

Table I lists the database search strings that formed the basis of this review. The review of relevant studies led to a thematic categorization of the literature on money laundering and shell companies. The categorization foregrounds different aspects of the money laundering

process. Money laundering can be multi-faceted; for instance, the use of shell companies to launder funds does not rule out the use of banks in aiding the illicit activity. In such cases, only the most prominent part of the laundering technique is used for categorization purposes. Additionally, the focus on money laundering literature is derived from the fact that shell companies are used to launder the proceeds of illicit activities such as drug-trafficking, robberies, smuggling, tax evasion, terrorism, bootlegging, art theft, vehicle theft, fraud and so forth (Mitchell et al., 1998a, Mitchell et al., 1998b). As a result, it becomes imperative to understand the work done around money laundering before focusing explicitly on shell companies and its uses in undertaking illicit activities.

The next section provides a brief overview of research on money laundering and its related aspects. Following this, current works investigating shell companies are discussed to highlight the gaps in the literature.

\section{Classification of literature on money laundering}

The review led to categorization of the literature on money laundering into six broad categories as exhibited in Figure 1, namely, anti-money laundering (AML hereafter) framework and its effectiveness, effect of money laundering on other fields and the economy, role of actors and their relative importance, magnitude of money laundering, and new opportunities for money laundering and its detection. The classification of the literature into the aforementioned broad but overlapping categories is to showcase the volume of work being undertaken concerning different aspects of money laundering. Such a cross-horizon review helps to identify areas that might have been overlooked or that have not been extensively researched. The following sub-sections provide an analysis of the key research in each of these categories.

\section{--Insert approximately here--Figure 1. Classification of literature on money laundering}




\subsection{AML framework and its effectiveness}

A fast-growing literature exists on AML and counter financing of terrorism (CFT hereafter) framework and regulations. The effectiveness of the AML regime and its effect on illicit activities such as money laundering, terrorism, financing of crime and crime prevention and detection have been of interest to scholars (Anand, 2011, Barone and Masciandaro, 2011, Brzoska, 2016, Chaikin, 2009, Ferwerda, 2009, Harvey, 2008, Huang, 2015, Masciandaro, 1998, Masciandaro and Portolano, 2003, Pellegrina and Masciandaro, 2009, Unger et al., 2014). The interest arises out of the need to provide sufficient justification for the cost incurred in implementing these regulations and their effectiveness in achieving the desired objectives.

Masciandaro (1998) and Masciandaro and Portolano (2003) termed AML legislation to be costly because of their negative effect on the efficiency of domestic and international banking. Huang (2015) provided a macro-level analysis of the AML legislation present in the US, including the reasons underlying their implementation. The study examined the value of US AML regime on the banking sector and observed it to have adverse socio-economic effects, in terms of fear of compliance and violation of regulations. Other jurisdictions have also been studied. Alberto (2016) examined the effectiveness of a new Spanish Act of financial ownership to combat money laundering and financing of terrorism by comparing it with models of France and Germany. He found the act to have shortcomings in terms of data protection, automation in processing of personal data and access of information by third parties without consent. Aurasu and Aspalella (2018) conducted a comparative analysis of Money Laundering Acts between the UK and Malaysia in terms of their forfeiture regime. These two countries share a similar legislation structure which facilitated comparison. It was concluded that the UK's money laundering Act is more comprehensive than the Malaysian Act in terms of offences covered and the standard of proof. However, Norton (2018) critiqued the UK's AML legislative changes and highlighted its failure to clearly define "suspicious activity", thus leading to a low threshold to report. As a result, there was a notable increase in the volume of reporting by auditors.

Jakobi (2018) examined the global AML regime from a security governance perspective and concluded that AML clearly represents the elements of security governance. Pol (2018a) extended this literature by focusing on AML practices and their effectiveness as a policy against defined outcomes as set by FATF. He found that FATF methodologies are not effective and a better implementation is required to achieve effective results. Pol (2018b) 
further questioned the other assumptions upon which the global AML/CFT framework is based, that is, whether forfeiture of criminal assets is a good measure of evaluating success of AML policies and if their extension as an obligation for new sectors will have an effect.

Pellegrina and Masciandaro (2009) highlight the differences that exist between countries' national legislation about the criminalisation of money laundering activities. They suggest that eliminating the possibility of exploiting the differences between regulations across countries may help in enhancing the effectiveness of the AML regulations. The need for international cooperation in this improvement is supported by Ferwerda (2009). On the lines of assessing the effectiveness of AML regime, Barone and Masciandaro (2011) estimated the public benefit for Europe from a drastic reduction in the money laundering multiplier effect. They found the public benefits would outweigh the cost of AML regulations. Similarly, Barone and Schneider (2018) are of the view that a causal link exists such that effective AML regulations increase the costs for criminal organisations, which they describe as an efficient way to reduce money laundering.

The debate around the AML framework and its effectiveness has led to the rapidly changing regulatory landscape to combat the problem of illicit activities such as money laundering. This is demonstrated by the proposed changes made to the reforms to address the loopholes (AUSTRAC, 2018, Bozhilova, 2018). For instance, a list of proposed changes has been suggested to the existing EU's Fifth Anti-Money Laundering Directive to address the loopholes in regulation. The proposed changes address aspects related to exchange and use of information and to the cooperation between financial intelligence units (FIUs) of the member states as well as between FIUs and other competent authorities within the member states. The goal is to reduce opportunities for illicit actors to take advantages of national differences in the definition, scope and sanctioning of money laundering offences which results in suboptimal cooperation between concerned authorities. The proposed changes seek to be in line with other policies pursued by the EU such as the reformed data protection regime (Bozhilova, 2018). Table II summarises key works focusing on the effectiveness of AML.

\section{--Insert approximately here-- Table II. Overview of research on effectiveness of AML}

\subsection{Effect of money laundering on other fields and the economy}

Apart from critiquing the AML framework, researchers have also focused on the relation of money laundering with various other fields and its effect on the overall economy. The effect of money laundering and tax havens on each other has been examined by a number 
of scholars (Dharmapala and Hines, 2009, Masciandaro, 2008, Rose and Spiegel, 2007). Schwarz (2011) extended this literature by determining the incentives for tax havens to maintain low regulatory standards for attracting dirty money and thus providing money laundering services. Picard and Pieretti (2011) aimed at observing the effect of pressure policies such as blacklisting and sanctions on offshore financial centres (OFCs hereafter) and their ability to ensure compliance with AML regulations. Instead of analysing the desirability or harm of tax havens (Alstadsæter et al., 2018, Christensen, 2012, Chu et al., 2015), Picard and Pieretti focused on the incentives for offshore governments and banks to comply with AML regulations. They found that offshore banks would comply under pressure policies provided the pressure had potential to harm the reputation of investors.

Knowledge of accounting has always been essential and used by various stakeholders in promoting their respective interests (Kenno and Free, 2018), and, with the advent of technological innovations, the importance of accounting has only increased (Hoiberg, 1999). Compin (2008) assessed the importance of accounting knowledge in undertaking moneylaundering and terror-financing activities by using a theoretical approach. He concluded that money laundering and terror financing differ with respect to financial sophistication and psychological profile. Irwin et al. (2012) also found that money launderers and terrorist financiers exhibit different laundering techniques and launder different amounts; the techniques involved in money laundering are more complex and the asset value involved is greater, as compared with terrorist financing.

The importance of accounting practices in undertaking illicit activities such as money laundering and corruption, and facilitating a criminal network between the perpetuators, was supported by Mitchell et al. (1998b) and Neu et al. (2013). A large sum of money cannot be laundered without the help of accountants and other professionals who use their expertise to conceal and obscure the illicit source of funds. Mitchell et al. (1998a; 1998b) used case studies to examine the role of accountants in undertaking illicit activities. Before this study, the scrutiny of links between white-collar crimes and accountants was limited only to social scientists and was neglected by accounting academics. The study emphasised the involvement of accountants in money laundering and the unwillingness of regulators to investigate them. Ravenda et al. (2017) contributed to this by extending the literature on the use of accounting practices for undertaking money laundering activities to Italian mafia firms. Further to this, the need to focus on the use of forensic accounting and its knowledge to combat illicit activities has been emphasised by Botes and Saadeh (2018). 
The effect of money laundering on the economy and vice-versa has also been examined. According to Dowers and Palmreuther (2003) and Drayton (2002), money laundering harms the economy by causing monetary and socio-economic instability, economic distortions, and promoting corruption and a more vulnerable financial system. Stack (2015b) examined the role of money laundering organisations in Ukraine to facilitate tax-evasion and corruption. He found that a huge amount of dirty money is generated and used to satisfy the greed of State actors. Similarly, Hendriyetty and Grewal (2017), found that money laundering increases criminal activities, increases the shadow economy and reduces tax collections. On the other hand, Barone et al. (2018) analysed the effect of macroeconomic cycles on illicit capital and money-laundering activities to determine whether business cycles can influence trends and activities in illegal markets and money laundering. They found that during different economic cycles, the capacity of illegal capital that the market can sustain varies. Table III summarises key works about the effect of money laundering on other fields and the economy.

\section{-Insert approximately here-- Table III. Overview of research on the effect of money laundering on other fields and the economy}

\subsection{The role of actors and their relative importance}

Prior literature has studied the role of actors involved in money-laundering activities, those laundering for themselves, laundering on behalf of others and even those trying to prevent it.

It becomes quite vital to determine the importance and role of money launderers to undertake such illicit activity, consciously or unwittingly, to understand their source of motivation (Barone and Masciandaro, 2011, Barone et al., 2018, Barone and Schneider, 2018). Van Duyne (2003) and Reuter and Truman (2004) found that criminals generally laundered money themselves rather than hiring professionals to do it. On the other hand, Soudijn (2012) reported that professionals are an important part of criminal networks, but he did not specify their involvement in drug markets.

Malm and Bichler (2013) tried to address the question of who launders money and their respective role in the criminal network. The authors found the importance of moneylaunderers to be greater in the drug market than any other illicit market and found support for the notion of a social snowball effect whereby the social circle of an individual played an important role in entering the illicit drug market. This notion was reiterated by Gilmour 
(2015) who characterised the importance of social and cultural context of a person in influencing his decisions to commit an offence or not. On examining the importance of legal and finance professionals in money-laundering activities, Benson (2016) found that the decision to launder criminal proceeds is influenced by the nature of the occupational role, social relationships and dynamics, and the circumstances leading up to and surrounding the point at which the decision is made. Other research supports the importance of organisational climate and financial incentives in influencing actions of the concerned stakeholders (Andon et al., 2018, Kumar et al., 2018, Murphy and Free, 2016).

The decision to undertake a criminal activity can be attributed to cost-benefit analysis (Becker, 1968). McCarthy et al. (2015) attempted to address the effect of the kind of financial benefits being offered. The authors found that the payoff to the launderer increases when his legal wage rate increases, when the criminal's legal wage rate decreases and when the probability of detection increases.

The literature has also focused on actors responsible for curbing financial crimes such as money laundering. On analysing the extent of auditors' compliance with respect to legislative changes in UK's AML, Norton (2018) found the level of suspicious activity reporting by auditors to be relatively low in comparison with professionals from other sectors. He attributed it to having a standardised format for reporting suspicious activity and the nature of the profession whereby negative audit reports can result in auditors losing clients. While Liss and Sharman (2015) emphasised the growing importance of private actors to combat money laundering through the concept of global governmentality, Murray (2018b) and Howieson (2018) stressed the need to address wilful blindness and a lack of epistemic virtues in professional codes of conduct to minimise the opportunities for fraud and money laundering.

\subsection{Magnitude of money laundering}

A key aspect of understanding a problem is to know its magnitude. This allows the seriousness of the crime, its effect on the macroeconomy and the effectiveness of countermeasures to be evaluated over time. The same holds for money laundering. Researchers have attempted to quantify the extent to which money is being laundered (Quirk, 1997, Tanzi, 1996). One of the most notable works in this area is by Walker (1999). The study presented what has come to be known as the "Walker model of global money laundering" and it relies upon a wide range of publicly available databases. The model 
suggested the global amount of money being subject to laundering was USD 2.85 billion per year in 1999 with the most flows in Europe and North America.

Numerous researchers have since focused on quantifying the amount of money being laundered and how it is being laundered (Ardizzi et al., 2014, Argentiero et al., 2008, Barone and Masciandaro, 2011, Barone and Schneider, 2018, Biagioli, 2008, Ferwerda et al., 2013, Hassan and Schneider, 2016a, Hassan and Schneider, 2016b, Medina and Schneider, 2018, Schneider and Enste, 2000, Schneider, 2010, Schott, 2006, Unger, 2013, Unger and Hertog, 2012, Walker and Unger, 2009, Zdanowicz, 2004b, Zdanowicz, 2009). Researchers have used a variety of methods including the use of case studies, proxy variables and economic models. Unger (2013) classified ways of measuring money laundering into two categories, namely, using proxies (such as GDP, world-wide proceeds of crime and balance of payments discrepancies) and through the use of economic models (such as dynamic two-sector model and Walker-Gravity model).

\section{--Insert approximately here-- Table IV. Overview of research on the magnitude of money laundering}

However, there exists a school of thought that criticizes these estimates and deems them to be inaccurate and misleading in estimating the correct amount of funds being laundered (Levi and Reuter, 2006, Pol, 2018b, Reuter and Greenfield, 2001, Reuter and Truman, 2004, Thoumi, 2005). Unger (2013) attributed the lack of a precise estimate of the size of money laundering to the concealed nature of the underlying crime and the amount of proceeds generated. Table IV provides a snapshot of research on the magnitude of money laundering.

\subsection{New opportunities for money laundering}

Speer (2000) deemed the threat of cybercrime to be substantial and correctly projected it to grow with increases in knowledge about computers and other technologies. This new form of criminal activity essentially comprises a computer, a network and a human interface that allows the perpetrators to steal money using the network (Sood et al., 2013). Researchers have recently directed attention towards understanding the costs and proceeds of cybercrimes (Anderson et al., 2013, Levi et al., 2016, Levi et al., 2017, Schneider, 2017a, Schneider, 2017b, Schneider and Linsbauer, 2016). With a rapid transformation in crimes, it becomes imperative to distinguish between new cybercrimes and those that are e-enabled. Cybercrimes do not exist outside of the cyber domain, or at least their effect outside of the cyber domain is 
relatively low. E-enabled crimes, on the other hand, are existing criminal acts that have flourished because of easier use with technology (Burden and Palmer, 2003). Therefore, criminal activities such as hacking and malware attacks would be examples of cybercrimes whereas activities such as money laundering and phishing are e-enabled crimes. The extensive use of the online platform is an enabling factor in overcoming the constraints of a social network such as geographical or social barriers, and it facilitates collaboration with perpetrators across the globe, and thereby increasing the opportunity to commit illicit acts (Leukfeldt, 2014).

In line with the aforementioned observations, there has been growth in the moneylaundering literature based on the new opportunities that have become available for laundering of funds and carrying out illicit activities. These opportunities have come about because of rapid advances in technology. Barone and Schneider (2018) view cyberlaundering and money laundering accomplished through the use of automatic electronic devices as a growing threat.

Irwin et al. (2012) proposed that an understanding of the modus operandi for money laundering and terror financing could be used for developing typologies for the virtual world. Further, Richet (2013) made use of an online ethnography approach to determine new cybermethods for laundering funds. He found two key forces providing opportunities for money laundering - online gaming, and micro-laundering which involves moving a small amount of funds over a large number of transactions. He concluded that traditional methods of laundering funds have evolved through the online medium and an understanding of the modus operandi of such new methods would enable better detection. This has led to some work being undertaken to monitor new opportunities that may have become available to launder funds.

By analysing E-Gold and Liberty Reserve fraud cases, Stuhlmiller (2013) found that the anonymity of virtual currency transactions and lack of regulatory oversight were prominent catalysts for their use as new laundering methods. On the contrary, Dostov and Shust (2014), on investigating cryptocurrencies such as Digicash and Bitcoin and the threats they pose towards money laundering and financing of terrorism, found that the feature of anonymity is unlikely to make them popular among its users. According to them, cryptocurrencies have limitations in terms of negotiability, risk and the need for specialised training. In other words, as there is no universal acceptability for cryptocurrencies, the need to exchange them for fiat money arises at some point. Secondly, cryptocurrencies such as Bitcoins are unequally 
distributed and are highly volatile, which makes them unattractive. Dostov and Shust also stressed the importance of examining each cryptocurrency and their respective characteristics separately to develop an appropriate regulatory framework. The need to have a regulatory framework in place to combat the threats posed by cryptocurrencies towards money laundering and financing of terrorism is supported by Choo (2015).

To address the problem of anonymity and untraceable nature of cryptocurrency transactions, Turner and Irwin (2018) made an attempt to de-anonymise Bitcoin transactions using a variety of software tools. The authors found that while it was possible to follow a transaction across the blockchain, the anonymity feature inherent in the system was not overcome. The technological innovations have paved new ways to perpetuate organised crimes. Silk Road is one such example that has drawn attention from academics and enforcement agencies alike (Barratt, 2012, Bright et al., 2012, Christin, 2012, Hout and Bingham, 2013).

\subsection{Detection of money laundering}

With the growing focus on illicit activities, the academic literature has emphasised coming up with a wide variety of automated detection systems to detect such illicit activities (Baader and Krcmar, 2018, Battaglia et al., 2018, Chang et al., 2008, Gepp, 2016, Gepp et al., 2018, Gepp, 2015, Khaled et al., 2018, Ngai et al., 2011, Perols, 2011, Phua et al., 2010, Ravenda et al., 2015, Sahin et al., 2013, Singh and Best, 2019, Song et al., 2014, Van Vlasselaer et al., 2017, Wedge et al., 2017). As per Ngai et al. (2011), although the application of data-mining techniques has been extended towards the detection of insurance fraud, there exists a distinct lack of research on mortgage fraud, money laundering and securities and commodities fraud.

Since then researchers have investigated both machine-learning and traditional statistical approaches to detect money laundering (Irwin et al., 2012, Bidabad, 2017, Chang et al., 2008, Deng et al., 2009, Drezewski et al., 2012, Colladon and Remondi, 2017, Gao and Ye, 2007, Gilmour, 2017, Ju and Zheng, 2009, Ngai et al., 2011, Perols, 2011, Regan et al., 2017, Savage et al., 2016, Savage, 2017, Turner and Irwin, 2018, Unger et al., 2011, Wang et al., 2007, Zdanowicz, 2004a, Zdanowicz, 2009, Zhang et al., 2003, Gao, 2009). Zhang et al. (2003) on using Link Discovery based on Correlation Analysis (LDCA) suggested that the possibility of being associated with a money-laundering scheme would depend upon the correlation between the financial transaction patterns of two persons. Zdanowicz (2004a), 
Zdanowicz (2009) proposed the use of statistical analysis to monitor and detect trade-based money laundering. He extended the empirical evidence of trade-based money laundering in academic and professional literature. He stated that detection of trade-price manipulations by identifying anomalies in trade data may help in detecting money laundering of funds derived from activities such as for financing the acts of terrorism, tax avoidance or evasion, dumping of goods, concealment of illegal commission and so forth by focusing on country, customs district, product and transaction price-risk characteristics.

Chang et al. (2008) highlighted the use of a set of coordinated visualisations based upon keywords identification in wire transactions to detect fraudulent transactions. The authors on depicting the relationship between keywords and accounts over time were able to detect transactions and accounts exhibiting suspicious behaviours. Similarly, Deng et al. (2009) came up with an active learning sequential design (ALSD) approach to detect instances of money laundering. The study was motivated by the need to identify and prioritise relevant suspicious transactions among the large volume of financial transactions that occurred on a daily basis. The idea was to help investigators focus attention and direct resources to accounts which are suspicious in nature and improve money-laundering detection with minimal time and efforts. The authors found the model to outperform stochastic approximations in detecting money-laundering transactions. Savage et al. (2016) presented a system for detection through the use of combination of network analysis and supervised learning. The authors on using the system on real-world data found it was able to detect suspicious activity with a low rate of false positives. Table $\mathrm{V}$ presents key research on the detection of money laundering and other illicit activities.

\section{--Insert approximately here-- Table V. Overview of research on detection of money laundering and other illicit activities}

Overall, the literature has focused on attempting to detect money laundering being undertaken through the use of real estate, international trade and high-value portable goods among others as exhibited by Figure 2. Ferwerda et al. (2013), Zdanowicz (2009) and Unger (2013) directed attention towards detection of money laundering being undertaken through real estate and trade. Turner and Irwin (2018) found opportunities provided by technological innovations such as bitcoin to launder money and suggested ways to detect it. Gilmour (2017) studied the use of high-value portable commodities being used to launder funds in the UK 
and abroad. Bidabad (2017) suggested mechanisms to detect money laundering being undertaken through the use of banking transactions.

\section{--Insert approximately here-- Figure 2. Literature on detection of money laundering}

However, the detection of money laundering through shell companies has received limited attention. In other words, attempts towards identifying shell companies being used for illicit activities such as bribery, corruption and money laundering are in a nascent stage. The next section would provide an overview of shell companies and the limited work that has been undertaken in relation to them.

\section{Shell companies}

\section{--Insert approximately here--Figure 3. Current literature around shell companies} --Insert approximately here--Figure 4. Uses of shell companies

A review of the literature on shell companies led to classification into five broad categories as exhibited in Figure 3: namely, shell companies and their legitimate uses, illicit uses of shell companies, the effectiveness of regulations related to shell companies, importance of transparency and detection of illicit shell companies. The following subsections provide a brief overview through key papers in each of these categories. The legitimate and illegitimate/illicit uses of shell companies are further described in Figure 4.

\subsection{Shell companies and their legitimate uses}

Shell Companies, also known as front companies or anonymous companies, are entities with either no or minimal operations and assets, and generally they do not exhibit a physical presence. Private companies with an intention to become publicly listed may use shell companies (Aydogdu et al., 2007). According to Floros and Sapp (2011), the purpose of shell firms can be gaining a tax advantage, avoiding legal liability, facilitating collection of income from patents and other such intangible assets, but the majority of these entities aim to be acquired or to merge with another firm.

The use of publicly-listed shell companies by private companies to go public is called reverse mergers. A substantial amount of literature exists examining the use of shell 
companies for reverse mergers, and the benefits as well as the associate disadvantages (Aydogdu et al., 2007, Chen et al., 2016, Chen and Soileau, 2014, Floros and Sapp, 2011, Gleason et al., 2005, Lee et al., 2015, Poulsen and Stegemoller, 2008, Semenenko, 2011, Sjostrom, 2008). Table VI provides a snapshot of the research on legitimate uses of shell companies.

\section{--Insert approximately here-- Table VI. Overview of research on shell companies and their legitimate uses}

Aydogdu et al. (2007) deemed reverse mergers efficient and cost-effective as several requirements associated with an Initial Public Offering (IPO) can be avoided. They examined the trading activity around reverse mergers to search for market-wide stock price manipulation and did not find any evidence of such manipulation. They observed that merger announcements are considered positive as reflected by increasing stock prices and statistically significant positive returns. However, the results were inconclusive as to whether reverse mergers are value-increasing events for shell companies.

Chen and Soileau (2014) on comparing the earnings quality of US-based domestic firms extended the literature on reverse mergers by finding that they have lower earnings quality compared with IPO firms during the period from 1997 to 2011. Lee et al. (2015) added to the knowledge of performance, financial health, benefits and disadvantages of reverse mergers by comparing the after-merger return performance of US control firms with that of Chinese reverse mergers.

\subsection{Illicit uses of shell companies}

Apart from being used in reverse mergers, shell companies are used as holding companies or for protecting small entrepreneurs from bankruptcy risks. They are also referred to as fictitious entities, sham companies, front companies and pass throughs or anonymous companies, and are often used for a wide range of illicit activities such as bribery, corruption, financial statement fraud, tax evasion, terrorist financing, money laundering, sanction evasion and cybercrimes (Findley et al., 2013, Hubbs, 2018). The literature, both professional and academic, available on shell companies has focused on its illicit uses (Cooley et al., 2018, Cowdock, 2017, Does de Willebois et al., 2011, Findley et al., 2013, Findley et al., 2015, Gup and Beekarry, 2009, Harding, 2016, Hubbs, 2018, Jancsics, 2017, Stack, 2015b, Stack, 2015c). Table VII summarises the key works with a focus on illicit uses of shell companies. 


\section{--Insert approximately here-- Table VII. Overview of research on illicit uses of shell companies}

Gup and Beekarry (2009) analysed the characteristics of limited liability companies and the extent to which they pose a threat to money laundering and terror financing. The characteristic traits of these entities such as secrecy, flexibility, low cost of incorporation and compliance requirements made them an attractive tool for illicit actors. They found that LLCs provide opportunities for tax evasion, regulatory evasion, money laundering and financing the acts of terrorism, among others. The authors suggested the need to focus on due-diligence requirements and increasing transparency. Additionally, they point out that FATF recommendations concerning anonymous entities are limited. They also direct attention towards FATF's acknowledgement of the need to do more to tackle money laundering risks arising out of LLCs. Singh (2010), using a case study analysis, attempted to identify the attributes of shell companies in India and made recommendations for Indian regulatory authorities. He observed that these entities were used for rotation and siphoning of funds, creation of equity in their names, and for holding real estate properties. Similarly, Does de Willebois et al. (2011) point towards the use of legal structures in the UK to accomplish such illicit activities. On observing one hundred and fifty cases of large-scale corruption, they found that many cases involved the use of shell companies to hide illicit wealth.

Stack (2015c) analysed the role of shell companies in Latvian-type correspondent banking and resulting money-laundering operations. He examined financial flows from Russia and the former Soviet Union and highlighted the use of shell companies in movement of funds from those associated with corruption and organised crime. He found that these entities moved funds from Russia, Ukraine and other Soviet countries through international correspondent banking relations to offshore savings accounts and business suppliers. Jancsics (2017) added to this discussion by describing how corporate vehicles are used by corrupt public officials in Hungary. The study aimed at understanding the reasons for using shell companies in corrupt transactions, identifying the sectors which these entities are most frequently used in, the actors responsible for interaction through these entities and the political and social context for their existence. He found that all the reported cases of corruption were related to public policy decisions and involved the use of shell companies. They were used mainly in the tobacco and agricultural sectors with the objective of distribution of resources for client-building or for market capture. 
The intensive use of shell companies for illicit purposes by a wide range of users was highlighted in the report known as the Panama Papers by the International Consortium of Investigative Journalists (Harding, 2016, Obermayer et al., 2016). Similarly, Cooley et al. (2018) detail various instances of the way shell companies have been used by kleptocrats to launder funds.

The literature has also emphasised the important role that offshore centres and tax havens have played in the growth of shell companies (Alstadsæter et al., 2018, Christensen, 2011, Christensen, 2012, Picard and Pieretti, 2011, Sikka and Willmott, 2010, Stack, 2015b, Stack, 2015c, Stack, 2015a, Zucman et al., 2015). Sikka and Willmott (2010) examined the role of tax havens and shell companies to avoid and evade taxes. The authors observed that 26 per cent of assets and 31 per cent of net profits of American multinational corporations were in tax havens and over three thousand major US companies were sheltering in the US Virgin Islands and Barbados alone. The authors found that entities would sell their products to trading subsidiaries at below market prices, and they in turn sell the products to end customers at market prices and pocket the difference. The trade subsidiaries located in tax havens were generally shell companies. Similarly, Christensen (2011), Christensen (2012) and Harding (2016) highlighted the role of tax havens in facilitating shell companies to hide and disguise illicit financial flows and beneficial ownership and thus aiding in corruption. Zucman et al. (2015) highlighted that shell companies and offshore accounts allow the rich to invest at home and abroad under a shroud of anonymity, thus facilitating evasion of taxes. According to Alstadsæter et al. (2018), ten per cent of the total world's Gross Domestic Product (GDP) is held in tax havens with the most being in British Virgin Islands, Panama and other such tax havens where the wealth is held mainly through shell corporations.

\subsection{Effectiveness of regulations related to shell companies}

The possible damage associated with the use of shell companies comprises financial losses, both direct and indirect, reputational damage, loss of operations and possibility of lawsuits. Therefore, the use of these entities should be of immense concern to legal and compliance professionals, business partners and agents, wholesalers, customers, government officials especially tax officials, anti-corruption non-governmental organisations (NGOs hereafter), and so forth. The scholarly attention received has resulted in suggestions and recommendations being made as well as the reasons being identified for the failure to combat this growing problem (Allred et al., 2017, Bateman, 2016, Cowdock, 2017, Does de Willebois et al., 2011, Findley et al., 2013, Findley et al., 2015, Gilbert and Sharman, 2016, 
Gup and Beekarry, 2009, Ho, 2017, Hubbs, 2018, Jancsics, 2017, Lee and Palstra, 2018, Murray, 2018a, Niels and Gabriel, 2014, Pol, 2018a, Pol, 2018b, Sharman, 2012, Sharman, 2013, Vail, 2018, Vaughan, 2018, Zucman et al., 2015).

Bateman (2016) emphasised the need to have a legal framework for regulating shell companies. Efforts have been made to increase the transparency of such entities by providing beneficial ownership information to prevent such entities from being used for money laundering, corruption, bribery, terrorism financing and other such crimes. The FATF, the international institution responsible for overseeing corporate transparency, and the G20 have continuously urged countries to implement standards for regulating beneficial ownership information to increase trust in businesses, improve corporate accountability and to facilitate successful combating of illicit practices (Ho, 2017). Similarly, Vail (2018) emphasised the need to have transparent beneficial owner information, a shared beneficial owner registry and the ways to accomplish it. However, despite the emphasis placed on transparency through international standards and recommendations, the incidence of non-compliance highlights the failure of policymakers and scholars to assess the effectiveness of policies. They tend not to consider the countervailing pressures faced by democratic governments to tackle the problems of corruption, which at times may be related to personal benefit or electoral incentives.

Sharman (2012) stated shell companies that cannot be traced to real owners acted as a corporate veil to conceal the proceeds of crime and corruption. The emphasis on corporate transparency would help law enforcement agents to catch wrongdoers. As per Sharman (2012) the information on beneficial owners could be accessed in two ways. First, the corporate registry is required to collect and hold information with proofs about the identities of beneficial owners. Another way is to regulate the company service providers (CSPs hereafter) who could collect information about the beneficial owners of entities and provide the same to regulators upon request. The CSPs may be individuals, law firms or other firms with the sole purpose of incorporating companies. They may be present in an OECD country, tax haven or a developing country and take care of the formalities required for establishing a company on behalf of a client, who would be the beneficial owner of the company (Sharman, 2013). There do exist international regulations such as the FATF guidelines to prevent use of legal entities to hide and transfer the proceeds of crime and corruption. They regulate licensing of CSPs, subjecting them to a legal duty of collecting, holding and verifying identification data and imposing penalties on failure to do so (FATF, 2012). Sharman (2012) 
attribute the unavailability of beneficial ownership information to a lack of resources devoted to determining them and to the high cost of enforcing international standards.

The efforts and resources directed towards fighting money laundering and corruption, therefore, depend upon restrictions to form anonymous companies. Findley et al. (2013) examined the effectiveness of regulations restricting the formulation of anonymous companies. The study was motivated by concerns surrounding the effectiveness of these restrictions because of different geographical locations of illicit actors and the legal domicile of CSPs. They found non-compliance with international standards requiring CSPs to obtain documentation identifying the beneficial owners. Anonymous companies were still being created and the presence of international standards did not result in an increase in compliance rates.

Findley et al. (2015) extended their previous study and found evidence that contradicts the common notion that OECD countries are compliant with international standards, while developing countries are unable to comply and tax havens are unwilling to comply. Overall, raising the standards of international law, in terms of strict regulations to comply with, was found to have no significant effect with material self-interest remaining a powerful tool to violate international standards. Allred et al. (2017) extended this research stream further with a focus on corporate governance and its execution. They found that country-level compliance with international standards is not an indicator of firm-level compliance, and this finding is consistent with Findley et al. (2015).

Gilbert and Sharman (2016), motivated by an overstated notion of compliance with international standards, shifted the focus of compliance with international standards from firms to States and governments to determine whether democracies would comply with international standards prohibiting foreign bribery. The study employed process-tracing case studies of British Aerospace, the Australian Wheat Board and the Reserve Bank of Australia and found evidence of wilful blindness by Australian and British governments in relation to the violation of the OECD Anti-Bribery Convention. The failure of democratic governments to investigate the crimes of their respective corporate citizens suggests a disinclination towards compliance rather than a lack of ability. Gilbert and Sharman also point to the need to better protect and encourage whistle-blowers, anti-corruption NGOs and investigative journalists. Similarly, Jancsics (2017) provides reasons for the failure of conventional anticorruption policies against shell companies in Central Europe, thereby further highlighting the fact that compliance frameworks alone are not enough. Among other findings, he found 
that actors do not rationally evaluate the possible outcome of their behaviour and so a stricter criminal code or stronger law enforcement may be ineffective. He also concluded that domestic shell companies are controlled by trusted individuals and there is no formal relationship or contract between the fake and real owners and thus even accurate and updated corporate registries will fail to reveal such connections.

\subsection{Importance of transparency}

The relationship between transparency and financial performance has been documented in the literature. Akhigbe et al. (2017) observed transparency having a positive effect on the financial performance of banks. Despite evidence of public and private actors' noncompliance and failure to implement regulations and recommended standards, efforts have been made by regulatory authorities and law-enforcement agencies to increase the transparency of beneficial ownership because of the widely accepted notion that greater transparency would facilitate prevention and detection of unlawful activities. With the Persons with Significant Control (PSC) regulations, the UK was the pioneer in making information available about the ultimate owners of a company in the corporate registry. Ho (2017) provided a brief background of the UK regulations and evaluated the implementation of similar regulation in Hong Kong. The idea behind PSC regulations in UK was to tackle tax evasion, corporate misconduct and other illicit activities. Instead of legal persons, the focus was on natural persons who actually own and take advantage of assets of a legal person and exercise control or influence. However, the regulations did not apply to all entities. The entities with voting shares listed on stock markets in the US, UK, Switzerland, Japan and other European Economic Area (EEA) were exempted.

Lee and Palstra (2018) conducted a study to evaluate the effectiveness of the UK's ownership register and highlight issues in ensuring the quality and compliance of data. They analysed over ten million records of data on PSCs from the UK Companies House and documented the limitations of the regulation, the lack of data validation and verification, the poor quality of data on the corporate registry and prevailing trends which could attract further analysis. Methods used to hide the real owners included filing a statement that the company had no owners, using an ineligible foreign company as the beneficial owner and using nominees or a circular ownership structure. The efforts directed to combat the problem associated with shell companies have been towards improve transparency. It is important to understand that achieving transparency should be one of the objectives and not the ultimate goal for preventing shell companies being misused. The need to have a global transparent 
governance regime is desirable but the application of such a regulation could be challenging and possibly even undesirable. Balakina et al. (2017) point out that the demand and supply for tax and financial havens exist on account of the need for banking secrecy. Therefore, implementing a transparent regime in one jurisdiction is likely to create a demand for secrecy and hence reduced transparency in another jurisdiction.

The existing literature on shell companies is focused on regulations related to international standards aiming to achieve transparency and their implementation, as well as the regulation of CSPs. The opportunity lies in using a more innovative approach in combating the hiding and laundering of illicit proceeds rather than focusing on improving the regulations.

\subsection{Detection of illicit shell companies}

This is a new research stream. The only study identified to have taken a step in this direction was by Luna et al. (2018). The lack of accessible real banking transaction data prompted the authors to develop a banking transaction simulator for shell and regular companies. The banking transaction simulator worked on multiple parameters affecting a company's banking activities such as industry sector, annual revenue category, and the number of employees, suppliers and utilities. Simulated incoming and outgoing transactions were analysed to look for patterns to help determine whether a bank account belongs to a shell company, or not. Each account was summarised by a set of features derived from the nature and timing of the money flows. Anomaly detection techniques were then used to detect variation between expected and observed business transaction profiles of regular and shell companies. The rationale was to identify shell companies that could be investigated further for any illicit activity. However, the model focused only on banking transactions and so did not make use of publicly available information such as the number of directors and their backgrounds, and whether transactions were made to tax havens or countries with a weak banking regime. There is a need for further research to analyse a dataset comprising real shell companies involved in illicit activities. There is also an opportunity to incorporate publicly available information in the detection of shell companies, thus avoiding the reliance upon the availability of banking transactions data.

\section{Discussion and Conclusion}




\section{--Insert approximately here-Figure 5. Framework for identification of research gap}

A typology on money laundering literature has been formulated, as depicted in Figure 5. A review of the current literature led to the identification of money laundering and shell companies as an important area that is currently under-researched. The existing research on money laundering has focused on the: (a). AML framework and its effectiveness: Researchers have critiqued the existing AML regime and drawn attention to its effectiveness; (b). Effect of money laundering on other fields and the economy: Prior research has investigated the effects of money laundering on the economy and its relationship with other fields such as accounting; (c). Role of actors and their relative importance: The role of actors such as accountants and auditors in undertaking money laundering and their respective importance has also been examined by researchers; (d). Magnitude of money laundering: In order to establish the gravity of the problem, researchers have made efforts to quantify the amounts of money being laundered globally; (e). New opportunities for money laundering: The technological and regulatory changes have also motivated works that highlight the new technology-enabled methods of laundering funds; (f). Detection of money laundering: There also exists some research directed towards the methods used to detect money laundering.

The final category has been further categorised into four broad groups - the detection of money laundering through (i) banking transactions, (ii) real estate and trade, (iii) innovative technologies and (iv) shell companies. On reviewing the literature on money laundering and its related areas, it was further identified that the detection of money laundering through shell companies had received limited attention. The existing literature on shell companies is focused on regulations related to international standards aiming to achieve transparency and their implementation as well as regulation of CSPs.

The rise in financial crimes has led to a wide range of regulatory reforms to combat the problem. The debate over the effectiveness of regulations to accomplish the desired objectives has brought the regulators under pressure to justify their actions in the face of political, executive and judicial scrutiny. This has eventually led to risk colonisation, that is, risk playing an imperative role in defining the aspects, methods and rationale for regulations (Rothstein et al., 2006). However, instances of regulatory failures have raised the question of whether the regulatory strategies can be adjusted to the dynamics of real life to combat the problem. The present circumstances lay down the need for highly responsive regulation 
through a combination of various regulatory instruments to address the problem (Black and Baldwin, 2010). The attempts that have been made towards identifying shell companies being used for illicit activities such as bribery, corruption, money laundering, tax evasion and other such illicit activities are in a nascent stage because of the importance placed on making regulatory changes. However, the need for combining risk-based assessment with compliance-based assessment can act as an essential tool in the fight against financial crime. The development of a model to detect illicit shell companies being used to carry out illicit activities would aid in contributing to the development of a "really-responsive" regulatory framework by enhancing the performance of regulatory tasks. The different regulatory tasks encompass detection of a non-compliant behaviour followed by a response to such behaviour through the development of tools and strategies, their enforcement, assessment of their success or failures, and modifying them accordingly (Baldwin and Black, 2008). The detection of shell companies being used for illicit activities would assist in combatting the active use of shell companies to accomplish laundromat schemes such as the Russian Laundromat and Azerbaijani Laundromat. The motivation lies in developing an approach to detect the entities used for hiding and laundering of illicit proceeds rather than focusing on improving the regulations.

The research conducted in the past on shell companies and characteristics identified for detecting shell companies involved in illicit activities has been qualitative in nature. A quantitative analysis would be difficult given the limited and inherently concealed data on shell companies, but it would help uncover patterns among connected networks of companies identified in money-laundering cases of the past to develop strategies for their timely detection. Consequently, an approach to detect illicit shell companies through a quantitative framework by using traditional statistical and machine-learning approaches to develop models would be a value-addition in the enhancement of regulatory effectiveness. Such a model based on publicly available information could act as the first line of defence for lawenforcement agencies to guard the wider public and economy against the harmful effects of illicit shell companies. The authors join the call of Dunstan and Gepp (2018) who directed attention towards the use of Big Data applications to analyse data for developing models for detection and prediction of misconduct. The technological advancements have paved the way for exploring relational inductive biases within deep learning architectures to facilitate insights into entities and for producing structured behaviours (Battaglia et al., 2018). This was not possible in the past and hence taking advantage of such technological advancements 
could add to the breadth and depth of works on shell companies and to the overall money laundering literature.

The paper highlights the gap in the existing literature and lays down the foundation for future studies to develop strategies for detection of such illicit shell companies. The review highlights additional opportunities for exploring the effectiveness of AML regime and the steps that could be taken to make it effective in accomplishing the desired objectives rather than being a mere tool of compliance. The debate around quantifying the magnitude of the problem of money laundering and the lack of consensus around its measurement is again brought to light through the current study. Thus, there still exists an opportunity for researchers to more accurately quantify the magnitude of money laundering. The review on evaluating the new opportunities for money laundering through the use of innovative technology, consistent with Martin (2014), directs attention towards the transformation of drug distribution through online portals and the need for a potential paradigm shift in the global war on drugs, which at present, has been costly and ineffective in accomplishing its goals. For instance, an examination of the operations of Silk Road and drawing comparison with conventional drug distribution networks led to the conclusion that cybercrime typologies do not reflect the complexities associated with Silk Road as they treat activities on it as a single act rather than numerous offences linked by a common purpose (Martin, 2014). An examination of the effects on money laundering posed by the proliferation of crypto markets also provides an additional opportunity for further research.

Overall, the study sets the tone for further research work to be carried out in the area of money laundering, which is currently doing substantial damage to economies all over the globe. 


\section{References}

Akhigbe, A., McNulty, J. E. and Stevenson, B. A. (2017), "Additional evidence on transparency and bank financial performance", Review of Financial Economics, Vol. 32 No. 1, pp. 1-6.

Alberto, G. S. (2016), "Spain: financial ownership file and money laundering prevention", Journal of Money Laundering Control, Vol. 19 No. 3, pp. 238-248.

Allred, B. B., Findley, M. G., Nielson, D. and Sharman, J. C. (2017), "Anonymous Shell Companies: A Global Audit Study and Field Experiment in 176 Countries", Journal of International Business Studies, Vol. 48 No. 5, pp. 596-619.

Alstadsæter, A., Johannesen, N. and Zucman, G. (2018), "Who owns the wealth in tax havens? Macro evidence and implications for global inequality", Journal of Public Economics, Vol. 162, pp. 89-100.

Anand, A. I. (2011), "Combating Terrorist Financing: Is Canada’s Legal Regime Effective?", University of Toronto Law Journal, Vol. 61 No. 1, pp. 59-71.

Anderson, R., Barton, C., Böhme, R., Clayton, R., Van Eeten, M. J., Levi, M., Moore, T. and Savage, S. (2013), "Measuring the cost of cybercrime", The economics of information security and privacy, Springer, pp. 265-300.

Andon, P., Free, C., Jidin, R., Monroe, G. and Turner, M. (2018), "The Impact of Financial Incentives and Perceptions of Seriousness on Whistleblowing Intention", Journal of Business Ethics, Vol. 151 No. 1, pp. 165-178.

Ardizzi, G., Petraglia, C., Piacenza, M., Schneider, F. and Turati, G. (2014), "Money Laundering as a Crime in the Financial Sector: A New Approach to Quantitative Assessment, with an Application to Italy", Journal of Money, Credit and Banking, Vol. 46 No. 8, pp. 1555-1590.

Argentiero, A., Bagella, M. and Busato, F. (2008), "Money laundering in a two-sector model: using theory for measurement", European Journal of Law and Economics, Vol. 26 No. 3, pp. 341-359.

Aurasu, A. and Aspalella, A. R. (2018), "Forfeiture of criminal proceeds under anti-money laundering laws: A comparative analysis between Malaysia and United Kingdom (UK)", Journal of Money Laundering Control, Vol. 21 No. 1, pp. 104-111.

AUSTRAC (2018), "Draft AML/CTF Rules", Australia, Australian Transaction Reports and Analysis Centre (AUSTRAC). 
Aydogdu, M., Shekhar, C. and Torbey, V. (2007), "Shell companies as IPO alternatives: an analysis of trading activity around reverse mergers", Applied Financial Economics, Vol. 17 No. 16, p. 1335.

Baader, G. and Krcmar, H. (2018), "Reducing false positives in fraud detection: Combining the red flag approach with process mining", International Journal of Accounting Information Systems, Vol. 31, pp. 1-16.

Balakina, O., D’Andrea, A. and Masciandaro, D. (2017), "Bank secrecy in offshore centres and capital flows: Does blacklisting matter?", Review of Financial Economics, Vol. 32, pp. 30-57.

Baldwin, R. and Black, J. (2008), "Really responsive regulation", The modern law review, Vol. 71 No. 1, pp. 59-94.

Barone, R., Delle Side, D. and Masciandaro, D. (2018), "Drug trafficking, money laundering and the business cycle: Does secular stagnation include crime?", Metroeconomica, Vol. 69 No. 2, pp. 409-426.

Barone, R. and Masciandaro, D. (2011), "Organized crime, money laundering and legal economy: theory and simulations", European Journal of Law and Economics, Vol. 32 No. 1, pp. 115-142.

Barone, R. and Schneider, F. G. (2018), "Shedding Light on Money Laundering. Is It a Damping Wave?", SSRN Electronic Journal.

Barratt, M. J. (2012), "Silk Road: EBay for Drugs", Addiction, Vol. 107 No. 3, pp. 683-684.

Bateman, L. R. (2016), "Shell companies: A regulatory and legal framework", in Pantani, P. (Ed., ProQuest Dissertations Publishing, , Utica College.

Battaglia, P. W., Hamrick, J. B., Bapst, V., Sanchez-Gonzalez, A., Zambaldi, V., Malinowski, M., Tacchetti, A., Raposo, D., Santoro, A., Faulkner, R., Gulcehre, C., Song, F., Ballard, A., Gilmer, J., Dahl, G., Vaswani, A., Allen, K., Nash, C., Langston, V., Dyer, C., Heess, N., Wierstra, D., Kohli, P., Botvinick, M., Vinyals, O., Li, Y. and Pascanu, R. (2018), "Relational inductive biases, deep learning, and graph networks", arXiv e-prints.

Becker, G. S. (1968), "Crime and Punishment: An Economic Approach", Journal of Political Economy, Vol. 76 No. 2, pp. 169-217.

Benson, K. (2016), "The facilitation of money laundering by legal and financial professionals: roles, relationships and response", The University of Manchester (United Kingdom). 
Biagioli, A. (2008), "Financial crime as a threat to the wealth of nations", Journal of Money Laundering Control, Vol. 11 No. 1, pp. 88-95.

Bidabad, B. (2017), "Money laundering detection system (MLD) (a complementary system of Rastin banking)", Journal of Money Laundering Control, Vol. 20 No. 4, pp. 354366.

Black, J. and Baldwin, R. (2010), "Really Responsive Risk-Based Regulation", Law \& Policy, Vol. 32 No. 2, pp. 181-213.

Botes, V. and Saadeh, A. (2018), "Exploring evidence to develop a nomenclature for forensic accounting", Pacific Accounting Review, Vol. 30 No. 2, pp. 135-154.

Bozhilova, K. (2018), "European Union: European Commission Proposes New Anti-Money Laundering Directives".

Bright, D., Hughes, C. and Chalmers, J. (2012), "Illuminating dark networks: a social network analysis of an Australian drug trafficking syndicate", Crime, Law and Social Change, Vol. 57 No. 2, pp. 151-176.

Brzoska, M. (2016), "Consequences of Assessments of Effectiveness for Counterterrorist Financing Policy", Administration \& Society, Vol. 48 No. 8, pp. 911-930.

Buchanan, B. (2004), "Money laundering - a global obstacle", Research in International Business and Finance, Vol. 18 No. 1, pp. 115-127.

Burden, K. and Palmer, C. (2003), "Internet crime: Cyber Crime - A new breed of criminal?", Computer Law \& Security Review, Vol. 19 No. 3, pp. 222-227.

Camdessus, M. (1998), "Money laundering: the importance of international countermeasures", in Plenary Meeting of the Financial Action Task Force on Money Laundering, Paris.

Chaikin, D. (2009), "How effective are suspicious transaction reporting systems?", Journal of Money Laundering Control, Vol. 12 No. 3, pp. 238-253.

Chang, R., Lee, A., Ghoniem, M., Kosara, R., Ribarsky, W., Yang, J., Suma, E., Ziemkiewicz, C., Kern, D. and Sudjianto, A. (2008), "Scalable and Interactive Visual Analysis of Financial Wire Transactions for Fraud Detection", Information Visualization, Vol. 7 No. 1, pp. 63-76.

Chen, K. C., Cheng, Q., Lin, Y. C., Lin, Y. C. and Xiao, X. (2016), "Financial reporting quality of Chinese reverse merger firms: The reverse merger effect or the weak country effect?", Accounting Review, Vol. 91 No. 5, pp. 1363-1390. 
Chen, Y. and Soileau, J. S. (2014), "Does pedigree matter? Earnings quality of U.S. listed domestic firms via reverse mergers", Journal of Accounting and Public Policy, Vol. 33 No. 6, pp. 573-595.

Choo, K. K. R. (2015), "Cryptocurrency and Virtual Currency: Corruption and Money Laundering/Terrorism Financing Risks?", Handbook of Digital Currency, Academic Press, San Diego, pp. 283-307.

Christensen, J. (2011), "The looting continues: tax havens and corruption", Critical Perspectives on International Business, Vol. 7 No. 2, pp. 177-196.

Christensen, J. (2012), "The hidden trillions: Secrecy, corruption, and the offshore interface", Crime, Law and Social Change, Vol. 57 No. 3, pp. 325-343.

Christin, N. (2012), "Traveling the Silk Road: A measurement analysis of a large anonymous online marketplace".

Chu, H., Lai, C. C. and Cheng, C. C. (2015), "Tax Havens, Growth, and Welfare", Journal of Public Economic Theory, Vol. 17 No. 6, pp. 802-823.

Colladon, A. F. and Remondi, E. (2017), "Using social network analysis to prevent money laundering", Expert Systems With Applications, Vol. 67, pp. 49-58.

Compin, F. (2008), "The role of accounting in money laundering and money dirtying", Critical Perspectives on Accounting, Vol. 19 No. 5, pp. 591-602.

Cooley, A., Heathershaw, J. and Sharman, J. C. (2018), "Laundering Cash, White Washing Reputations", Journal of Democracy, Vol. 29 No. 1, pp. 39-53.

Cowdock, B. (2017), "Hiding in Plain Sight: How UK Companies are used to launder corrupt wealth", United Kingdom, Transparency International UK.

Deng, X., Joseph, V. R., Sudjianto, A. and Wu, C. F. J. (2009), "Active Learning Through Sequential Design, With Applications to Detection of Money Laundering", Journal of the American Statistical Association, Vol. 104 No. 487, pp. 969-981.

Dharmapala, D. and Hines, J. R. (2009), "Which countries become tax havens?", Journal of Public Economics, Vol. 93 No. 9, pp. 1058-1068.

Does de Willebois, E. v. d., Halter, E. M., Harrison, R. A., Park, J. W. and Sharman, J. C. (2011), The Puppet Masters: How the Corrupt Use Legal Structures to Hide Stolen Assets and What to Do About It, The World Bank, Washington D.C.

Dostov, V. and Shust, P. (2014), "Cryptocurrencies: an unconventional challenge to the AML/CFT regulators?", Journal of Financial Crime, Vol. 21 No. 3, pp. 249-263. 
Dowers, K. and Palmreuther, S. (2003), "Developing an international consensus to combat money laundering and terrorism financing", Infrastructure and Financial Markets Review, Vol. 9 No. 1, pp. 1-7.

Drayton, F. R. (2002), "Dirty Money, Tax and Banking: Recent Developments Concerning Mutual Legal Assistance and Money Laundering in the Caribbean Region and the Region's Responses", Journal of Money Laundering Control, Vol. 5 No. 4, pp. 338344.

Drezewski, R., Sepielak, J. and Filipkowski, W. (2012), "System supporting money laundering detection", Digital Investigation, Vol. 9 No. 1, pp. 8-21.

Dunstan, K. and Gepp, A. (2018), "Guest editorial", Pacific Accounting Review, Vol. 30 No. 2, pp. 130-134.

FATF (2012), "The FATF Recommendations: International Standards on Combating Money Laundering and the Financing of Terrorism \& Proliferation", Financial Action Task Force.

Ferwerda, J. (2009), "The economics of crime and money laundering: Does anti-money laundering policy reduce crime?", Review of Law and Economics, Vol. 5 No. 2, pp. 903-929.

Ferwerda, J., Kattenberg, M., Chang, H. H., Unger, B., Groot, L. and Bikker, J. A. (2013), "Gravity models of trade-based money laundering", Applied Economics, Vol. 45 No. 22, pp. 3170-3182.

Findley, M. G., Nielson, D. L. and Sharman, J. C. (2013), "Using field experiments in international relations: A randomized study of anonymous incorporation", International Organization, Vol. 67 No. 4, pp. 657-693.

Findley, M. G., Nielson, D. L. and Sharman, J. C. (2015), "Causes of noncompliance with international law: A field experiment on anonymous incorporation", American Journal of Political Science, Vol. 59 No. 1, pp. 146-161.

Floros, I. V. and Sapp, T. R. A. (2011), "Shell games: On the value of shell companies", Journal of Corporate Finance, Vol. 17 No. 4, pp. 850-867.

Gao, Z. (2009), "Application of cluster-based local outlier factor algorithm in anti-money laundering", in Proceedings - International Conference on Management and Service Science, MASS 2009, p. <xocs:first xmlns:xocs=""/>.

Gao, Z. and Ye, M. (2007), "A framework for data mining-based anti-money laundering research", Journal of Money Laundering Control, Vol. 10 No. 2, pp. 170-179. 
Gepp, A. (2015), "Financial statement fraud detection using supervised learning methods", Gold Coast, Queensland, Bond University.

Gepp, A. (2016), "Addressing the problem of financial statement fraud: Better detection through improved models", 8th Asia-Pacific Interdisciplinary Research in Accounting (APIRA) Conference, Melbourne, Australia.

Gepp, A., Linnenluecke, M. K., O’Neill, T. J. and Smith, T. (2018), "Big data techniques in auditing research and practice: Current trends and future opportunities", Journal of Accounting Literature, Vol. 40, pp. 102-115.

Gilbert, J. A. and Sharman, J. C. (2016), "Turning a Blind Eye to Bribery: Explaining Failures to Comply with the International Anti-corruption Regime", Political Studies, Vol. 64 No. 1, pp. 74-89.

Gilmour, N. (2015), "Understanding the practices behind money laundering - A rational choice interpretation", International Journal of Law, Crime and Justice, Vol. 44 No. C.

Gilmour, N. (2017), "Blindingly obvious and frequently exploitable- Money laundering through the purchasing of high-value portable commodities", Journal of Money Laundering Control, Vol. 20 No. 2, pp. 105-115.

Gleason, K. C., Rosenthal, L. and Wiggins, R. A. (2005), "Backing into being public: an exploratory analysis of reverse takeovers", Journal of Corporate Finance, Vol. 12 No. 1, pp. 54-79.

Gup, B. E. and Beekarry, N. (2009), "Limited liability companies (LLCs) and financial crimes", Journal of Money Laundering Control, Vol. 12 No. 1, pp. 7-18.

Harding, L. (2016), "What are the Panama Papers? A guide to history's biggest data leak", The Guardian.

Harvey, J. (2008), "Just How Effective is Money Laundering Legislation?", Security Journal, Vol. 21 No. 3, pp. 189-211.

Hassan, M. and Schneider, F. (2016a), "Modelling the Egyptian Shadow Economy: A MIMIC model and A Currency Demand approach", Journal of Economics and Political Economy, Vol. 3 No. 2, pp. 309-339.

Hassan, M. and Schneider, F. (2016b), "Size and Development of the Shadow Economies of 157 Worldwide Countries: Updated and New Measures from 1999 to 2013", Journal of Global Economics, Vol. 04 No. 03.

Hendriyetty, N. and Grewal, B. S. (2017), "Macroeconomics of money laundering: effects and measurements", Journal of Financial Crime, Vol. 24 No. 1, pp. 65-81. 
Ho, J. K. S. (2017), "Disclosure of beneficial ownership of companies in Hong Kong", Common Law World Review, Vol. 46 No. 4, pp. 251-268.

Hoiberg, P. (1999), "Accounting in the New Millennium", Pacific Accounting Review, Vol. 11 No. 1-2, pp. 131-136.

Hout, M. C. V. and Bingham, T. (2013), "Silk Road, the virtual drug marketplace: A single case study of user experiences", International Journal of Drug Policy, Vol. 24 No. 5, pp. 385-391.

Howieson, B. (2018), "What is the 'good' forensic accountant? A virtue ethics perspective", Pacific Accounting Review, Vol. 30 No. 2, pp. 155-167.

Huang, J. Y. (2015), "Effectiveness of US anti-money laundering regulations and HSBC case study", Journal of Money Laundering Control, Vol. 18 No. 4, pp. 525-532.

Hubbs, R. C. (2018), "Anonymous Shell Companies Rising", Fraud Magazine, Association of Certified Fraud Examiners.

Irwin, A. S. M., Kim-Kwang, R. C. and Liu, L. (2012), "An analysis of money laundering and terrorism financing typologies", Journal of Money Laundering Control, Vol. 15 No. 1, pp. 85-111.

Jakobi, A. P. (2018), "Governing illicit finance in transnational security spaces: the FATF and anti-money laundering", Crime, Law and Social Change, Vol. 69 No. 2, pp. 173190.

Jancsics, D. (2017), "Offshoring at Home? Domestic Use of Shell Companies for Corruption", Public Integrity, Vol. 19 No. 1, pp. 4-21.

Ju, C. and Zheng, L. (2009), "Research on Suspicious Financial Transactions Recognition Based on Privacy-Preserving of Classification Algorithm", in 2009 First International Workshop on Education Technology and Computer Science, pp. 525-528.

Kenno, S. A. and Free, C. (2018), "Fostering and forcing uses of accounting: Labourmanagement negotiations in the automotive crisis in Canada 2008-2009", Management Accounting Research, Vol. 39, pp. 17-34.

Khaled, H., Kuldeep, K. and Adrian, G. (2018), "Using Cutting-Edge Tree-Based Stochastic Models to Predict Credit Risk", Risks, Vol. 6 No. 2, p. 55.

Kumar, K., Bhattacharya, S. and Hicks, R. (2018), "Employee perceptions of organization culture with respect to fraud - where to look and what to look for", Pacific Accounting Review, Vol. 30 No. 2, pp. 187-198. 
Lee, A. and Palstra, N. (2018), "The Companies We Keep: What The UK's Open Data Register Actually Tells Us About Company Ownership", United Kingdom, Global Witness.

Lee, C. C., Li, K. K. and Zhang, R. (2015), "Shell games: The long-term performance of Chinese reverse-merger firms", Accounting Review, Vol. 90 No. 4, pp. 1547-1589.

Leukfeldt, E. R. (2014), "Cybercrime and social ties", Trends in Organized Crime, Vol. 17 No. 4, pp. 231-249.

Levi, M., Doig, A., Gundur, R., Wall, D. and Williams, M. (2016), "The implications of economic cybercrime for policing. City of London Corporation".

Levi, M., Doig, A., Gundur, R., Wall, D. and Williams, M. (2017), "Cyberfraud and the implications for effective risk-based responses: themes from UK research", Crime, Law and Social Change, Vol. 67 No. 1, pp. 77-96.

Levi, M. and Reuter, P. (2006), "Money laundering", Crime and Justice, Vol. 34 No. 1, pp. 289-375.

Levi, M. and Reuter, P. (2009), "Money Laundering", in Tonry, M. (Ed.) The Oxford Handbook of Crime and Public Policy, Oxford University Press, Oxfords, pp. 356380.

Liss, C. and Sharman, J. C. (2015), "Global corporate crime-fighters: Private transnational responses to piracy and money laundering", Review of International Political Economy, Vol. 22 No. 4, pp. 693-718.

Luna, D. K., Palshikar, G. K., Apte, M. and Bhattacharya, A. (2018), "Finding shell company accounts using anomaly detection", Proceedings of the ACM India Joint International Conference on Data Science and Management of Data, Goa, India, ACM pp. 167174.

Malm, A. and Bichler, G. (2013), "Using friends for money: the positional importance of money-launderers in organized crime", Trends in Organized Crime, Vol. 16 No. 4, pp. 365-381.

Martin, J. (2014), "Lost on the Silk Road: Online drug distribution and the 'cryptomarket', Criminology \& Criminal Justice, Vol. 14 No. 3, pp. 351-367.

Masciandaro, D. (1998), "Money Laundering Regulation: The Micro Economics", Journal of Money Laundering Control, Vol. 2 No. 1, pp. 49-58.

Masciandaro, D. (2008), "Offshore financial centres: the political economy of regulation", European Journal of Law and Economics, Vol. 26 No. 3, pp. 307-340. 
Masciandaro, D. and Portolano, A. (2003), "It takes two to tango: international financial regulation and offshore centres", Journal of Money Laundering Control, Vol. 6 No. 4, pp. 311-330.

McCarthy, K. J., van Santen, P. and Fiedler, I. (2015), "Modeling the money launderer: Microtheoretical arguments on anti-money laundering policy", International Review of Law \& Economics, Vol. 43, pp. 148-155.

Medina, L. and Schneider, F. (2018), "Shadow Economies Around the World", in Schneider, F. (Ed., Washington, D. C, International Monetary Fund.

Mitchell, A., Sikka, P. and Willmott, H. (1998a), The Accountants' Laundromat, Basildon: Association for Accountancy \& Business Affairs.

Mitchell, A., Sikka, P. and Willmott, H. (1998b), "Sweeping it under the carpet: The role of accountancy firms in moneylaundering", Accounting, Organizations and Society, Vol. 23 No. 5, pp. 589-607.

Murphy, P. R. and Free, C. (2016), "Broadening the Fraud Triangle: Instrumental Climate and Fraud", Behavioral Research in Accounting, Vol. 28 No. 1, pp. 41-56.

Murray, D. (2018a), "Protecting Our Elections: Examining Shell Companies and Virtual Currencies as Avenues for Foreign Interference", USA, Financial Integrity Network.

Murray, K. (2018b), "The cost of not wanting to know - the professions, money laundering and organised crime", Journal of Financial Crime, Vol. 25 No. 1, pp. 218-229.

Neu, D., Everett, J., Rahaman, A. S. and Martinez, D. (2013), "Accounting and networks of corruption", Accounting, Organizations and Society, Vol. 38 No. 6-7, pp. 505-524.

Ngai, E. W. T., Hu, Y., Wong, Y. H., Chen, Y. and Sun, X. (2011), "The application of data mining techniques in financial fraud detection: A classification framework and an academic review of literature", Decision Support Systems, Vol. 50 No. 3, pp. 559-569.

Niels, J. and Gabriel, Z. (2014), "The End of Bank Secrecy? An Evaluation of the G20 Tax Haven Crackdown", American Economic Journal: Economic Policy, Vol. 6 No. 1, pp. 65-91.

Norton, S. D. (2018), "Suspicion of money laundering reporting obligations: Auditor compliance, or sceptical failure to engage?", Critical Perspectives on Accounting, Vol. 50, pp. 56-66.

Obermayer, B., Ryle, G., Guevara, M. W., Hudson, M., Bernstein, J., Fitzgibbon, W., Cabra, M., Hamilton, M., Obermaier, F. and Chittum, R. (2016), "Giant leak of offshore financial records exposes global array of crime and corruption", OCCRP. The International Consortium of Investigative Journalists. 
OCCRP (2017), "The Azerbaijani Laundromat", The Organized Crime and Corruption Reporting Project.

OCCRP (2019), "The Troika Laundromat", The Organized Crime and Corruption Reporting Project.

Pellegrina, L. D. and Masciandaro, D. (2009), "The risk-based approach in the New European anti-money laundering legislation: A law and economics view", Review of Law and Economics, Vol. 5 No. 2, pp. 931-952.

Perols, J. (2011), "Financial statement fraud detection: An analysis of statistical and machine learning algorithms", Auditing, Vol. 30 No. 2, pp. 19-50.

Phua, C., Lee, V., Smith, K. and Gayler, R. (2010), "A Comprehensive Survey of Data Mining-based Fraud Detection Research", arXiv preprint arXiv:1009.6119.

Picard, P. M. and Pieretti, P. (2011), "Bank secrecy, illicit money and offshore financial centers", Journal of Public Economics, Vol. 95 No. 7, pp. 942-955.

Pol, R. (2018a), "Anti-money laundering effectiveness: assessing outcomes or ticking boxes?", Journal of Money Laundering Control, Vol. 21 No. 2, pp. 215-230.

Pol, R. (2018b), "Uncomfortable truths? ML=BS and AML= BS2", Journal of Financial Crime, Vol. 25 No. 2, pp. 294-308.

Poulsen, A. B. and Stegemoller, M. (2008), "Moving from Private to Public Ownership: Selling Out to Public Firms versus Initial Public Offerings", Financial Management, Vol. 37 No. 1, pp. 81-101.

Quirk, P. (1997), "Macroeconomic implications of money laundering", Trends in Organized Crime, Vol. 2 No. 3, pp. 10-14.

Ravenda, D., Argilés-Bosch, J. M. and Valencia-Silva, M. M. (2015), "Detection Model of Legally Registered Mafia Firms in Italy", European Management Review, Vol. 12 No. 1, pp. 23-39.

Ravenda, D., Valencia, M. M., Josep, M. A. and Josep, G. B. (2017), "Accrual management as an indication of money laundering through legally registered Mafia firms in Italy", Accounting, Auditing \& Accountability Journal, Vol. 31 No. 1, pp. 286-317.

Regan, S., Adams, H., Guiral, P. and Chouri, S. (2017), "Evolving AML Journey Leveraging Machine Learning Within Anti-Money Laundering Transaction Monitoring", Accenture Consulting.

Reuter, P. and Greenfield, V. (2001), "Measuring global drug markets", World economics, Vol. 2 No. 4, pp. 159-173. 
Reuter, P. and Truman, E. (2004), Chasing Dirty Money: The Fight Against Anti-Money Laundering, Peterson Institute for International Economics, Washington DC.

Richet, J. L. (2013), "Laundering Money Online: a review of cybercriminals methods". Rose, A. K. and Spiegel, M. M. (2007), "Offshore Financial Centres: Parasites or Symbionts?", Economic Journal, Vol. 117 No. 523, pp. 1310-1335.

Rothstein, H., Huber, M. and Gaskell, G. (2006), "A theory of risk colonization: The spiralling regulatory logics of societal and institutional risk", Economy and Society, Vol. 35 No. 1, pp. 91-112.

Sahin, Y., Bulkan, S. and Duman, E. (2013), "A cost-sensitive decision tree approach for fraud detection", Expert Systems with Applications, Vol. 40 No. 15, pp. 5916-5923.

Savage, D. (2017), "Detection of Illicit Behaviours and Mining for Contrast Patterns", RMIT University.

Savage, D., Wang, Q., Chou, P., Zhang, X. and Yu, X. (2016), "Detection of money laundering groups using supervised learning in networks".

Schneider, F. (2010), "Turnover of organized crime and money laundering: some preliminary empirical findings", Public Choice, Vol. 144 No. 3, pp. 473-486.

Schneider, F. (2017a), "The Dark Side: Crime Has Gone Global", A Closer Look at Globalization-The Positive Facets and the Dark Faces of a Complex Notion, Gütersloh.

Schneider, F. (2017b), "Restricting or Abolishing Cash: An Effective Instrument for Fighting the Shadow Economy, Crime and Terrorism?", in International Cash Conference 2017-War on Cash: Is there a Future for Cash?

Schneider, F. and Enste, D. H. (2000), "Shadow Economies: Size, Causes, and Consequences", Journal of Economic Literature, Vol. 38 No. 1, pp. 77-114.

Schneider, F. and Linsbauer, K. (2016), "The Financial Flows of Transnational Crime and Tax Fraud: How much cash is used and what do we (not) know?", in Cash on Trial, p. 83.

Schneider, F. and Windischbauer, U. (2008), "Money laundering: some facts", European Journal of Law and Economics, Vol. 26 No. 3, pp. 387-404.

Schott, P. A. (2006), Reference guide to anti-money laundering and combating the financing of terrorism, The World Bank.

Schwarz, P. (2011), "Money launderers and tax havens: Two sides of the same coin?", International Review of Law \& Economics, Vol. 31 No. 1, pp. 37-47. 
Semenenko, I. (2011), "Reverse merger waves, market timing and managerial behavior", International Research Journal of Applied Finance, Vol. 2 No. 12, pp. 1453-1481.

Sharman, J. (2012), "Tackling shell companies: Limiting the opportunities to hide proceeds of corruption", Chr. Michelsen Institute.

Sharman, J. (2013), "Preventing the misuse of shell companies by regulating corporate service providers", Chr. Michelsen Institute.

Sikka, P. and Willmott, H. (2010), "The dark side of transfer pricing: Its role in tax avoidance and wealth retentiveness", Critical Perspectives on Accounting, Vol. 21 No. 4, pp. $342-356$.

Singh, D. (2010), "Incorporating with fraudulent intentions: A Study of Various

Differentiating Attributes of Shell Companies in India", Journal of Financial Crime, Vol. 17 No. 4, pp. 459-484.

Singh, K. and Best, P. (2019), "Anti-Money Laundering: Using data visualization to identify suspicious activity", International Journal of Accounting Information Systems.

Sjostrom, W. K. (2008), "The truth about reverse mergers", Entrepreneurial Business Law Journal, Vol. 2 No. 2, pp. 743-759.

Song, X., Hu, Z., Du, J. and Sheng, Z. (2014), "Application of Machine Learning Methods to Risk Assessment of Financial Statement Fraud: Evidence from China", Journal of Forecasting, Vol. 33 No. 8, pp. 611-626.

Sood, A., Bonsal, R. and Enbody, R. (2013), "Cybercrime: Dissecting the State of Underground Enterprise", Ieee Internet Computing, Vol. 17 No. 1, pp. 60-68.

Soudijn, M. (2012), "Removing excuses in money laundering", Trends in Organized Crime, Vol. 15 No. 2, pp. 146-163.

Speer, D. L. (2000), "Redefining borders: The challenges of cybercrime", Crime, Law and Social Change, Vol. 34 No. 3, pp. 259-273.

Stack, G. (2015a), "Baltic shells: on the mechanics of trade-based money-laundering in the former Soviet space", Journal of Money Laundering Control, Vol. 18 No. 1, pp. 8198.

Stack, G. (2015b), "Money laundering in Ukraine", Journal of Money Laundering Control, Vol. 18 No. 3, pp. 382-394.

Stack, G. (2015c), "Shell companies, Latvian-type correspondent banking, money laundering and illicit financial flows from Russia and the former Soviet Union", Journal of Money Laundering Control, Vol. 18 No. 4, pp. 496-512. 
Stuhlmiller, L. (2013), "Mitigating virtual money laundering: An analysis of virtual worlds and virtual currencies", in Lynch, S. (Ed., United States -- New York, Utica College.

Tanzi, V. (1996), "Money Laundering and the International Financial System", International Monetary Fund.

Thoumi, F. E. (2005), "The numbers game: let's all guess the size of the illegal drug industry!", Journal of Drug Issues, Vol. 35 No. 1, pp. 185-200.

Turner, A. and Irwin, A. S. M. (2018), "Bitcoin transactions: a digital discovery of illicit activity on the blockchain", Journal of Financial Crime, Vol. 25 No. 1, pp. 109-130.

Unger, B. (2013), "Can Money Laundering Decrease?", Public Finance Review, Vol. 41 No. 5, pp. 658-676.

Unger, B., Ferwerda, J., Nelen, H. and Ritzen, L. (2011), Money laundering in the real estate sector: Suspicious properties, Edward Elgar, Cheltenham.

Unger, B., Ferwerda, J., Van Der Broek, M. and Deleanu, I. (2014), The economic and legal effectiveness of the european union's anti-money laundering policy, Edward Elgar, Cheltenham, England; Northampton, Massachusetts.

Unger, B. and Hertog, J. (2012), "Water always finds its way: Identifying new forms of money laundering", Crime, Law and Social Change, Vol. 57 No. 3, pp. 287-304.

UNODC (2004), "United Nations Convention Against Transnational Organized Crime and the Protocols Thereto", Vienna, United Nations.

Vail, N. (2018), "Cracking Shells: The Panama Papers and Looking to the European Union's Anti-Money Laundering Directive as a Framework for Implementing\&nbsp; Multilateral Agreement to Combat the Harmful Effects of Shell Companies", Texas A\&M Law Review, Vol. 5 No. 1, pp. 133-153.

Van Duyne, P. (2003), "Money Laundering Policy: Fears and Facts", Criminal Finances and Organizing Crime in Europe, Wolf Legal Publishers, Nijmegen, pp. 72-109.

Van Duyne, P. and Levi, M. (2005), Drugs and money managing the drug trade and crimemoney in Europe, Routledge, London; New York.

Van Vlasselaer, V., Eliassi-Rad, T., Akoglu, L., Snoeck, M. and Baesens, B. (2017), "GOTCHA! Network-Based Fraud Detection for Social Security Fraud", Manage. Sci., Vol. 63 No. 9, pp. 3090-3110.

Vaughan, G. (2018), "Shell companies, the role of company and trust service providers, and alternative banking platforms highlighted in NZ Police money laundering report".

Walker, J. (1999), "How Big is Global Money Laundering?", Journal of Money Laundering Control, Vol. 3 No. 1, pp. 25-37. 
Walker, J. and Unger, B. (2009), "Measuring global money laundering", Review of law and economics, Vol. 5 No. 2, pp. 821-853.

Wang, Y., Xu, D., Wang, H., Ye, K. and Gao, S. (2007), "Agent-oriented ontology for monitoring and detecting money laundering process", Proceedings of the 2nd international conference on Scalable information systems, Suzhou, China, ICST (Institute for Computer Sciences, Social-Informatics and Telecommunications Engineering) pp. 1-4.

Wedge, R., Kanter, J. M., Rubio, S. M., Perez, S. I. and Veeramachaneni, K. (2017), "Solving the" false positives" problem in fraud prediction", arXiv preprint arXiv:1710.07709.

Zdanowicz, J. S. (2004a), "Detecting money laundering and terrorist financing via data mining", Communications of the ACM, Vol. 47 No. 5, pp. 53-55.

Zdanowicz, J. S. (2004b), "U.S. Trade with the World and Al Qaeda Watch List Countries 2001: An Estimate of Money Moved Out of and Into the U.S. Due to Suspicious Pricing in International Trade".

Zdanowicz, J. S. (2009), "Trade-based money laundering and terrorist financing", Review of Law and Economics, Vol. 5 No. 2, pp. 855-878.

Zhang, Z., Salerno, J. J. and Yu, P. S. (2003), "Applying data mining in investigating money laundering crimes", in Proceedings of the ACM SIGKDD International Conference on Knowledge Discovery and Data Mining, pp. 747-752.

Zucman, G., Fagan, T. L. and Piketty, T. (2015), The Hidden Wealth of Nations : The Scourge of Tax Havens, University of Chicago Press, Chicago, IL. 